\title{
Suplementasi vitamin A dan asupan zat gizi dengan serum retinol dan morbiditas anak 1-3 tahun ${ }^{1}$
}

Vitamin A supplementation and nutrient intake with retinol serum and morbidity among children 1-3 years

\author{
Milliyantri Elvandari², Dodik Briawan ${ }^{3}$, Ikeu Tanziha ${ }^{3}$
}

${ }^{2}$ Magister Gizi Masyarakat, Fakultas Ekologi Manusia Institut Pertanian Bogo

${ }^{3}$ Departemen Gizi Masyarakat, Fakultas Ekologi Manusia Institut Pertanian Bogor

\begin{abstract}
Background: Morbidity of infectious diseases in developing countries is a public health concern because the prevalence is still high, particularly for children under five years. Vitamin A intake was one of factors that may affect morbidity. Objective: The objective of this study was to analyze relation between vitamin A supplementation, nutrition intake with vitamin A status and relation between vitamin A supllementation, nutrition intake, vitamin A status with morbidity. Method: The study was an cross-sectional study. This research was conductedin February-March 2016 in Kudus and Grobogan Central Java. Subjectsin this study were children aged 1-3 years $(n=140)$. Retinol serum was collected by taking blood sample through the vein then was analyzed using HPLC, nutrients intake with food recall $2 \times 24 j$ jam, and structured interviews with mother children. Data were analyzed with Chi-Square test. Results: The study found that 68 subjects (48.6\%) were not took vitamin A supplemantation capsule. Prevalence of childrens had nutrient deficiency $(<90 \%$ RDA) were relatively high $68.6 \%$ energy; $47.1 \%$ protein; $70.7 \%$ fat; and the prevalence of vitamin $A$ defeciency $(<77 \%$ RDA) were relatively high $60 \%$. A number of $24.2 \%$ subjects had low retinol serum $(<20 \mu \mathrm{g} /$ dl). Supplementation vitamin $A$, fat and vitamin $A$ intake correlated with retinol serum ( $p<0.05)$. Supplementation vitamin $A$, intake of vitamin $A$, vitamin $C$, zinc and retinol serum correlated with morbidity $(p<0.05)$. Conclusion: Childrens who were not took vitamin A supplemantation capsule, deficiency intake of vitamin A, vitamin $C$, zinc and low retinol serum had higher morbidity.
\end{abstract}

KEY WORDS: morbidity; retinol serum; vitamin A supplementation

\begin{abstract}
ABSTRAK
Latar belakang: Morbiditas penyakit infeksi di negara berkembang merupakan masalah kesehatan masyarakat karena prevalensi masih tinggi terutama untuk anak di bawah lima tahun. Asupan vitamin A merupakan salah satu faktor penyebab yang dapat mempengaruhi morbiditas. Tujuan: Menganalisis hubungan suplementasi vitamin A dan asupan gizi dengan serum retinol serta hubungan suplementasi vitamin A, asupan gizi, dan serum retinol dengan morbiditas anak usia 1-3 tahun. Metode: Desain penelitian cross-sectional yang dilaksanakan bulan Februari-Maret 2016 di Kabupaten Kudus dan Grobogan, Jawa Tengah. Subjek dalam penelitian ini adalah anak usia 1-3 tahun $(\mathrm{n}=140)$. Serum retinol dikumpulkan dengan mengambil sampel darah melalui vena kemudian dianalisis menggunakan HPLC, asupan zat gizi dengan food recall 2x24jam, dan wawancara terstruktur dengan ibu subjek. Analisis data yang digunakan adalah uji Chi-Square. Hasil: Studi ini menemukan bahwa 68 subjek $(48,6 \%)$ tidak mengambil suplementasi vitamin A. Prevalensi anak-anak memiliki asupan gizi kurang $(<90 \%$ AKG) yang relatif tinggi yaitu sebesar $68,6 \%$ untuk asupan energi; $47,1 \%$ protein; $70,7 \%$ lemak; dan prevalensi defisiensi vitamin $\mathrm{A}(<77 \% \mathrm{AKG})$ yang relatif tinggi sebesar $60 \%$. Sejumlah $24,2 \%$ subjek memiliki serum retinol rendah $(<20 \mu \mathrm{g} / \mathrm{dl})$. Suplementasi vitamin A, lemak, dan asupan vitamin A berhubungan dengan retinol serum $(\mathrm{p}<0,05)$. Suplementasi vitamin $\mathrm{A}$, asupan vitamin $\mathrm{A}$, vitamin $\mathrm{C}$, zink, dan serum retinol berhubungan dengan morbiditas $(\mathrm{p}<0,05)$. Simpulan: Anak yang tidak mengambil kapsul vitamin A serta asupan vitamin $\mathrm{A}$, vitamin $\mathrm{C}$, zink, dan retinol serum yang rendah memiliki morbiditas yang lebih tinggi.
\end{abstract}

KATA KUNCI: morbiditas; serum retinol; suplementasi vitamin A

\footnotetext{
Dipresentasikan pada $7^{\text {th }}$ International Symposium on Wellness, Healthy Lifestyle and Nutrition pada tanggal 3-4 November 2016 di Yogyakarta yang diselenggarakan oleh Departemen Gizi Kesehatan, Fakultas Kedokteran Universitas Gadjah Mada, Indonesia kerjasama dengan Universiti Sains Malaysia, Malaysia dan Prince of Songkla University, Thailand

Korespondensi: Milliyantri Elvandari, Program Magister Gizi Masyarakat, Fakultas Ekologi Manusia Institut Pertanian Bogor, Jl. Kamper, Kampus IPB Darmaga, Bogor, Jawa Barat, Indonesia, e-mail: milly.elvandari@gmail.com
} 


\section{PENDAHULUAN}

Derajat kesehatan masyarakat yang optimal adalah tingkat kondisi kesehatan yang tinggi dan mungkin dicapai jika kondisi dan situasi serta kemampuan dari setiap anggota masyarakat dan harus selalu diupayakan peningkatan secara terus-menerus. Oleh karena itulah selalu dilakukan berbagai upaya dalam menanggulangi berbagai masalah kesehatan (1). Anak usia 1-3 tahun adalah kelompok umur yang rentan terhadap gangguan kesehatan terutama penyakit infeksi, karena pada usia 1-3 tahun sudah mulai mengenal lingkungan luar dan dapat memilih makanan sendiri walupun tetap dengan bimbingan orang tua. Di berbagai negara berkembang termasuk Indonesia, penyakit diare masih menjadi salah satu masalah kesehatan masyarakat yang penting karena merupakan penyumbang utama ketiga morbiditas dan mortalitas anak. Diare merupakan menyebab 3,2 juta morbiditas dan mortalitas balita per tahun $(2,3)$.

Berdasarkan data WHO tahun 2010 pada Weekly Morbidity and Mortality Report (WMMR), dilaporkan bahwa pada minggu ke-22 (29 Mei-4 Juni 2010) dari semua jumlah kunjungan pasien, 12\% diantaranya adalah kasus penyakit diare dan dari semua jumlah kunjungan pasien, $23 \%$ diantaranya adalah balita, dan yang menderita penyakit diare adalah $9 \%$ dari semua jumlah kunjungan pasien balita (4). Sementara di Indonesia, prevalensi diare pada tahun 2013 lebih kecil (3,5\%) dibandingkan dengan prevalesi diare tahun 2007 (9\%) sedangkan prevalensi infeksi saluran pernapasan akut (ISPA) tahun 2013 (25\%) tidak jauh berbeda dengan tahun 2007 (25,5\%). Meskipun demikian, harus tetap dilakukan penanganan secara berkala (5). Prevalensi pneumonia pada tahun 2007 sebesar 11,2\% meningkat menjadi 18,5\% pada tahun 2013 (6). Berdasarkan data profil kesehatan Indonesia tahun 2013, lima besar morbiditas dan mortalitas pada anak usia 1-4 tahun di Indonesia adalah ISPA (25,8\%); pneumonia $(21,7 \%)$; demam (14\%); diare dan gastroenteritis (14,4\%) (5). Menurut Dinas Kesehatan Provinsi Jawa Tengah penemuan dan penanganan diare pada balita sebesar $42,6 \%$ (7).

Program pemberian suplementasi vitamin A merupakan program pemerintah di seluruh daerah di Indonesia. Rerata cakupan secara nasional di Indonesia mencapai 85,8\% dan Jawa Tengah merupakan cakupan kapsul vitamin A tertinggi kedua setelah Yogyakarta
(98,39\%) (6). Menurut data Dinas Kesehatan Jawa Tengah, terdapat kabupaten yang memiliki cakupan kapsul vitamin A tinggi dan rendah yaitu Kabupaten Kudus untuk cakupan tinggi (95\%) dan Kabupaten Grobongan dengan cakupan rendah (65,5\%) (7). Suplementasi vitamin A menurunkan morbiditas penyakit demam, diare, campak, dan memperbaiki status gizi (wasting, underweight) (8).

Salah satu faktor penting dalam upaya mencapai derajat kesehatan yang optimal pada anak adalah keadaan gizi yang baik. Namun, pada kenyataanya sampai saat ini di dalam masyarakat masih terdapat berbagai kekurangan gizi pada anak. Penyebab langsung masalah gizi secara garis besar terkait dengan konsumsi makanan yang masih kurang dibandingkan dengan kebutuhan serta adanya penyakit infeksi. Kebutuhan zat gizi untuk tubuh dapat diperoleh melalui asupan makanan yang mengandung sumber zat gizi makro (energi, protein, lemak) dan mikro (vitamin dan mineral) yang semuanya berperan dalam pertumbuhan anak (9). Berdasarkan data riset kesehatan dasar (Riskesdas) tahun 2013, prevalensi gizi kurang di Indonesia sebesar 19,6\% (6). Nilai prevalensi gizi kurang cukup tinggi di Indonesia dibandingkan standar yang ditetapkan World Health Organization (WHO) yaitu sebesar 10\%. Sementara menurut Dinas Kesehatan Provinsi Jawa Tengah, persentase balita dengan gizi kurang sebesar 17,6\% (7).

Vitamin A, vitamin C, dan zink berfungsi untuk pemeliharaan kesehatan dan kelangsungan hidup melalui sistem imunitas. Kekurangan vitamin A, vitamin C, dan zink dapat meningkatkan risiko anak terhadap penyakit infeksi seperti penyakit saluran pernapasan, diare, dan demam. Di samping itu, meningkatnya penyakit infeksi dapat menyebabkan keterlambatan pertumbuhan (10). Kekurangan vitamin A pada populasi dapat dilakukan pemeriksaan secara biokimia dengan pemeriksaan serum retinol darah (11). Indikator defisiensi vitamin A antara lain dapat dilihat dari konsentrasi retinol (12). Anakanak kekurangan vitamin A berisiko terhadap penyakit pernapasan dan meningkatkan keparahan penyakit diare (13). Berdasarkan pertimbangan di atas, secara umum penelitian ini bertujuan untuk menganalisis pengaruh suplementasi vitamin A dan asupan zat gizi dengan serum retinol dan morbiditas anak usia 1-3 tahun di Jawa Tengah. 


\section{BAHAN DAN METODE}

Desain penelitian ini menggunakan desain cross-sectional yang dilaksanakan pada bulan Februari sampai Maret 2016 di Kabupaten Kudus dan Grobogan, Jawa Tengah. Dua kabupaten yang dipilih berdasarkan cakupan suplementasi vitamin A tinggi dan rendah yaitu Kabupaten Kudus dan Kabupaten Grobongan. Dinas Kesehatan Kabupaten Kudus dan Grobongan merekomendasikan kecamatan yang mewakili cakupan suplementasi vitamin A tinggi dan rendah yaitu Kecamatan Undaan dan Kecamatan Gubug. Di Kecamatan Undaan dipilih tiga desa untuk mewakili cakupan suplementasi vitamin A tinggi yang memiliki kriteria yang sama yaitu desa Wonosoco, Berugenjang, dan Lambangan sedangkan untuk Kecamatan Gubug dipilih tiga desa untuk mewakili cakupan suplementasi vitamin A rendah yaitu desa Tambakan, Jati, dan Pranten. Subjek adalah anak berusia 1-3 tahun dari tiga desa di setiap kecamatan yang memenuhi kriteria inklusi yaitu anak sehat (tidak menderita infeksi) berdasarkan hasil pemeriksaan dokter setempat, ibu memberikan izin kepada tim peneliti untuk mengambil sampel darah anak, dan mematuhi prosedur penelitian yang sebelumnya sudah dijelaskan. Besar sampel minimal diperoleh berdasarkan hasil perhitungan rumus dengan melihat perubahan setidaknya $10 \%$ dari kosentrasi serum retinol dalam darah anak (14); standar deviasi $(\sigma)$ sebesar 14,2 $\mu \mathrm{g} / \mathrm{dl}$; dan peningkatan serum retinol $\left({ }^{\delta}\right) \delta$ ) sebesar $8,1 \mu \mathrm{g} / \mathrm{dl}$ sehingga dibutuhkan sampel minimal sebanyak 70 subjek di setiap Kecamatan (15).

Data berat badan dan tinggi badan diperoleh dengan pengukuran subjek, asupan zat gizi dengan food recall $2 \times 24$ jam, serum retinol darah dengan pengambilan darah vena kemudian diukur dengan menggunakan metode high performance liquid cromotography (HPLC). Sementara data karakteristik subjek, data morbiditas (jenis penyakit infeksi: diare, ISPA, demam, batuk), frekuensi sakit, dan lama sakit dikumpulkan dengan cara wawancara terstruktur menggunakan kuesioner. Asupan zat gizi adalah rerata asupan zat gizi yang dikonsumsi dibandingkan dengan angka kecukupan gizi (AKG). Asupan energi dan protein dikategorikan menjadi defisit $(<90 \%$ AKG) dan normal ( $>90 \%$ AKG). Asupan lemak dikategorikan menjadi kurang $(<20-35 \%$ AKE) dan cukup (>20-35\% AKE) (16). Asupan vitamin A, vitamin $\mathrm{C}$, dan zink dikategorikan menjadi kurang $(<77 \%$ AKG) dan cukup (>77\% AKG) (11). Hasil serum retinol darah dikategorikan menjadi rendah (10-20 $\mu \mathrm{g} / \mathrm{dl})$ dan normal (20-50 $\mu \mathrm{g} / \mathrm{dl})$ (17). Skor morbiditas diperoleh dari frekuensi sakit dikali dengan lama sakit per penyakit infeksi. Total dari skor morbiditas per penyakit infeksi di jumlah dengan penyakit infeksi lainya yang diderita kemudian dihitung rerata skor dan dikategorikan menjadi tinggi jika di atas skor rata-rata dan rendah jika di bawah skor rata-rata.

Analisis univariat dilakukan dengan menyajikan distribusi frekuensi dari variabel-variabel yang diteliti. Analisis bivariat dilakukan dengan menggunakan uji ChiSquare untuk melihat pengaruh suplementasi vitamin A dan asupan zat gizi terhadap serum retinol dan morbiditas anak usia 1-3 tahun di Jawa Tengah.

\section{HASIL}

\section{Analisis univariat}

Sebaran jenis kelamin subjek di Kudus sebagian besar berjenis kelamin laki-laki $(51,4 \%)$ sedangkan Grobogan sebagian besar perempuan (51,4\%). Program pemberian suplementasi vitamin A dilakukan dua kali dalam satu tahun yaitu pada bulan Februari dan Agustus. Berdasarkan hasil penelitian menunjukan bahwa di Kudus sebesar 54,3\% subjek mendapatkan suplementasi vitamin A dua kali dalam satu tahun sedangkan untuk Grobogan sebesar 51,4\% subjek hanya mendapatkan suplementasi vitamin A satu kali dalam satu tahun terakhir pada tahun 2015 (Tabel 1).

Kecukupan asupan energi, protein, lemak, vitamin A, vitamin $\mathrm{C}$, dan zink anak usia 1-3 tahun yaitu 1.125 kkal/hari; 26 g/hari; 44 g; 400 RE; 40 mg; dan 4 mg (18). Sebagian besar tingkat kecukupan energi, protein, dan lemak pada subjek tergolong defisit ( $>50 \%)$. Demikian juga dengan tingkat kecukupan vitamin $\mathrm{A}$, vitamin $\mathrm{C}$, dan zink subjek sebagian besar kurang $(>50 \%)$. Berdasarkan hasil analisis HPLC, rerata serum retinol subjek sebesar $27,9 \pm 6,3 \mu \mathrm{g} / \mathrm{dl}$ dan status serum retinol sebagian besar subjek di Kudu (82,9\%) dan Grobogan (92,9\%) tergolong serum retinol normal. Morbiditas adalah indikator penting dalam suatu wilayah untuk mencerminkan keadaan 
Tabel 1. Sebaran jenis kelamin, suplementasi vitamin A, asupan zat gizi, serum retinol, dan morbiditas

\begin{tabular}{lccc}
\hline Variabel & Kudus & Grobogan & Rerata \pm \\
\cline { 2 - 3 } SD
\end{tabular}

kesehatan suatu wilayah. Rerata skor total penyakit infeksi subjek sebesar 26,1 \pm 13 dan sebagian besar subjek memiliki skor morbiditas tinggi yaitu di Kudus sebesar 61,4\% dan Grobogan sebesar 52,9\% (Tabel 1).

\section{Hubungan suplementasi vitamin A dan asupan zat gizi dengan serum retinol}

Hasil analisis menunjukkan terdapat hubungan antara suplementasi vitamin A dengan serum retinol $(p<0,05)$. Subjek yang mendapatkan suplementasi vitamin A lengkap memiliki morbiditas penyakit infeksi yang rendah dibandingkan dengan anak yang tidak lengkap mendapatkan suplementasi vitamin A dalam satu tahun terakhir. Tidak terdapat hubungan antara asupan energi, protein, dan lemak dengan serum retinol anak $(p>0,05)$. Sebagian besar subjek dengan tingkat kecukupan energi dan protein normal dan defisit memiliki serum retinol normal karena banyak faktor lain yang mempengaruhi serum retinol selain asupan energi dan protein. Namun, terdapat hubungan antara asupan lemak dengan serum retinol $(p<0,05)$. Sebanyak $16,5 \%$ subjek dengan tingkat kecukupan lemak kurang memiliki morbiditas tinggi (Tabel 2). Demikian pula terdapat hubungan signifikan antara asupan vitamin A dengan serum retinol $(p<0,05)$. Sebanyak 19\% subjek dengan tingkat kecukupan vitamin A kurang memiliki morbiditas tinggi. Sebaliknya, tidak ditemukan hubungan signifikan antara asupan vitamin $C$ dan zink dengan serum retinol ( $p>0,05)$. Sebagian besar subjek dengan tingkat kecukupan vitamin $\mathrm{C}$ dan zinc normal dan defisit memiliki serum retinol normal.

\section{Hubungan suplementasi vitamin A, asupan zat gizi, dan serum retinol dengan morbiditas}

Tabel 3 menunjukkan bahwa terdapat hubungan suplementasi vitamin A dengan morbiditas $(p<0,05)$. Sebanyak $83,8 \%$ subjek tidak lengkap mendapatkan suplementasi vitamin A memiliki morbiditas tinggi. Tidak terdapat hubungan antara asupan energi, protein, dan lemak dengan morbiditas anak. Tingkat kecukupan energi, protein, dan lemak pada sebagian besar subjek tergolong normal dan memiliki morbiditas rendah. Selain itu, diketahui juga adanya hubungan yang signifikan antara tingkat kecukupan vitamin A, vitamin $\mathrm{C}$, dan zink dengan morbiditas $(\mathrm{p}<0,05)$. Sebagian besar tingkat kecukupan vitamin A, vitamin C, dan zink subjek tergolong kurang dan memiliki morbiditas tinggi. Lebih lanjut, hasil analisis menunjukkan adanya hubungan serum retinol dengan morbiditas $(\mathrm{p}<0,05)$. Sebagian besar subjek dengan serum retinol rendah memiliki morbiditas tinggi.

\section{BAHASAN}

Sebagian besar subjek di Kudus mendapatkan suplementasi vitamin A secara lengkap sedangkan sisanya yang tidak menerima karena ketika pembagian 
Tabel 2. Hubungan berbagai variabel dengan serum retinol

\begin{tabular}{|c|c|c|c|c|}
\hline Variabel & $\begin{array}{c}\text { Normal (0) } \\
\mathrm{n}(\%) \\
\end{array}$ & $\begin{array}{c}\text { Kurang (1) } \\
\mathrm{n}(\%)\end{array}$ & $\begin{array}{c}\text { OR } \\
95 \% \text { CI } \\
\end{array}$ & $\mathbf{p}$ \\
\hline \multicolumn{5}{|c|}{ Suplementasi vitamin A } \\
\hline Lengkap & $69(95,8)$ & $3(4,2)$ & 5,96 & $0,003 *$ \\
\hline Tidak Lengkap & $54(79,4)$ & $14(20,6)$ & $(1,63-21,81)$ & \\
\hline \multicolumn{5}{|l|}{ Energi (kkal) } \\
\hline Normal & $42(95,5)$ & $2(4,5)$ & 3,88 & 0,060 \\
\hline Defisit & $81(84,4)$ & $15(15,6)$ & $(0,84-17,81)$ & \\
\hline \multicolumn{5}{|l|}{ Protein (g) } \\
\hline Normal & $68(91,9)$ & $6(8,1)$ & 2,26 & 0,120 \\
\hline Defisit & $55(83,3)$ & $11(16,7)$ & $(0,78-6,51)$ & \\
\hline \multicolumn{5}{|l|}{ Lemak (g) } \\
\hline Cukup & $40(97,6)$ & $1(2,4)$ & 7,71 & $0,024 *$ \\
\hline Kurang & $83(83,8)$ & $16(16,2)$ & $(0,98-60,21)$ & \\
\hline \multicolumn{5}{|l|}{ Vitamin A (RE) } \\
\hline Cukup & $55(98,2)$ & $1(1,8)$ & 12,94 & $0,002 *$ \\
\hline Kurang & $68(81)$ & $16(19)$ & $(1,66-100,65)$ & \\
\hline \multicolumn{5}{|l|}{ Vitamin C (mg) } \\
\hline Cukup & $14(100)$ & $0(0)$ & 1,15 & 0,140 \\
\hline Kurang & $109(86,5)$ & $17(13,5)$ & $(1,07-1,23)$ & \\
\hline \multicolumn{5}{|l|}{ Zink (mg) } \\
\hline Cukup & $42(91,3)$ & $4(8,7)$ & 1,68 & 0,380 \\
\hline Kurang & $81(86,2)$ & $13(13,8)$ & $(0,51-5,49)$ & \\
\hline
\end{tabular}

*Signifikan berhubungan $(\mathrm{p}<0,05)$

suplementasi vitamin A subjek dalam keadaan kurang sehat dan tidak berada di lingkungan tempat tinggal. Pemberian suplementasi vitamin A sangat penting karena selain untuk kesehatan mata, vitamin A juga penting untuk meningkatkan daya tahan tubuh. Anak-anak yang cukup mendapat vitamin A bila terkena diare, campak, atau penyakit infeksi lain, maka penyakit tersebut tidak mudah menjadi parah sehingga tidak membahayakan jiwa anak (19). Suplementasi vitamin A yang diberikan pada anak dapat mempengaruhi serum retinol dalam darah. Hasil penelitian ini menunjukan bahwa adanya hubungan suplementasi vitamin A dengan serum retinol $(p=0,003)$ yaitu subjek yang mendapatkan suplementasi vitamin A lengkap dalam satu tahun terakhir memiliki serum retinol dalam darah yang normal. Peningkatan konsentrasi serum retinol setelah pemberian suplementasi pada anak dapat memperbaiki kekurangan vitamin A(20). Pemberian suplementasi vitamin A 200.000 IU pada anak secara signifikan dapat meningkatkan serum retinol (21). Pemberian suplementasi vitamin A pada anak selama penyakit infeksi dapat meningkatkan serum retinol dan membantu mengatasi pneumonia, campak, serta menunjukkan pentingnya serum retinol untuk kemajuan program suplementasi vitamin A di Zambian (22).

Morbiditas merupakan derajat kesehatan suatu wilayah, pemberian suplementasi vitamin A dapat menurunkan morbiditas penyakit infeksi pada anak. Hasil penelitian ini menunjukan bahwa adanya hubungan suplementasi vitamin A terhadap morbiditas $(p=0,000)$, subjek yang tidak mendapatkan suplementasi vitamin A secara lengkap dalam satu tahun terakhir berisiko memiliki morbiditas tinggi penyakit infeksi. Suplementasi vitamin A yang diberikan dapat mengurangi morbiditas dan mortalitas secara spesifik pada anak usia 6-59 bulan di negara berkembang (23). Cakupan suplementasi vitamin A sebesar 87\% di Etopia Utara dapat menurunkan prevelensi demam, diare, dan bitot pada anak (8). Hasil penelitian yang mendukung juga menemukan adanya hubungan yang signifikan antara suplementasi vitamin A dengan morbiditas balita di Kecamatan Jeumpa Kabupaten Bireuen (24). Namun sebaliknya, hasil penelitian lain tidak menemukan perbedaan proporsi penyakit pneumonia, 
Tabel 3 Hubungan berbagai variabel terhadap morbiditas

\begin{tabular}{|c|c|c|c|c|}
\hline Variabel & $\begin{array}{c}\text { Rendah } \\
\text { n (\%) }\end{array}$ & $\begin{array}{l}\text { Tinggi } \\
\text { n (\%) }\end{array}$ & $\begin{array}{c}\text { OR } \\
95 \% \mathrm{CI}\end{array}$ & $\mathbf{p}$ \\
\hline \multicolumn{5}{|c|}{ Suplementasi vitamin A } \\
\hline Lengkap & $49(68,1)$ & $23(31,9)$ & 11,04 & $0,000 *$ \\
\hline Tidak Lengkap & $11(16,2)$ & $57(83,8)$ & $(4,89-24,90)$ & \\
\hline \multicolumn{5}{|l|}{ Energi (kkal) } \\
\hline Normal & $22(50,0)$ & $22(50,0)$ & 1,52 & 0,240 \\
\hline Defisit & $38(39,6)$ & $58(60,4)$ & $(0,74-3,13)$ & \\
\hline \multicolumn{5}{|l|}{ Protein (g) } \\
\hline Normal & $35(47,3)$ & $39(52,7)$ & 1,47 & 0,260 \\
\hline Defisit & $25(37,9)$ & $41(62,1)$ & $(0,74-2,89)$ & \\
\hline \multicolumn{5}{|l|}{ Lemak (g) } \\
\hline Cukup & $21(51,2)$ & $20(48,8)$ & 1,61 & 0,190 \\
\hline Kurang & $39(39,4)$ & $60(60,6)$ & $(0,77-3,36)$ & \\
\hline \multicolumn{5}{|l|}{ Vitamin A (RE) } \\
\hline Cukup & $31(55,4)$ & $25(44,6)$ & 2,35 & $0,015^{*}$ \\
\hline Kurang & $29(34,5)$ & $55(65,5)$ & $(1,17-4,70)$ & \\
\hline \multicolumn{5}{|l|}{ Vitamin C (mg) } \\
\hline Cukup & $11(78,6)$ & $3(21,4)$ & 5,76 & $0,004 *$ \\
\hline Kurang & $49(38,9)$ & $77(61,1)$ & $(1,53-21,69)$ & \\
\hline \multicolumn{5}{|l|}{ Zink (mg) } \\
\hline Cukup & $32(69,6)$ & $14(30,4)$ & 5,38 & $0,000^{*}$ \\
\hline Kurang & $28(29,8)$ & $66(70,2)$ & $(2,50-11,61)$ & \\
\hline \multicolumn{5}{|l|}{ Serum retinol $(\mu \mathrm{g} / \mathrm{dl})$} \\
\hline Normal & $58(47,2)$ & $65(52,8)$ & 6,69 & $0,006^{*}$ \\
\hline Rendah & $2(11,8)$ & $15(88,2)$ & $(1,46-30,51)$ & \\
\hline
\end{tabular}

*Signifikan berhubungan $(\mathrm{p}<0,05)$

demam, dan campak pada anak yang menerima atau tidak kapsul vitamin A, bahkan proporsi ISPA dan diare pada balita yang menerima kapsul vitamin A lebih tinggi dibanding anak yang tidak menerima kapsul vitamin A. Hal ini diduga disebabkan oleh beberapa faktor yang mempengaruhi waktu survei, distribusi kapsul, faktor perancu, dan kejadian ISPA dan diare (25).

Kesehatan anak dipengaruhi oleh jenis makanan yang dikonsumsi dan penggunaan zat gizi yang terdapat dalam makanan. Tingkat kecukupan energi, protein, lemak, vitamin A, vitamin $\mathrm{C}$, dan zink berhubungan dengan serum retinol dan morbiditas anak. Tingkat kecukupan energi subjek sebagian besar defisit sedangkan tingkat kecukupan protein tergolong normal, tetapi rerata asupan energi dan protein subjek masih di bawah anjuran kecukupan energi yaitu sebesar 795 kkal dan 28,6 g. Rendahnya asupan energi dan protein subjek kemungkinan disebabkan oleh ibu subjek yang hanya memberikan makan pokok dua kali dalam sehari. Hasil penelitian menunjukan tidak adanya pengaruh tingkat kecukupan energi dan protein terhadap serum retinol ( $p=0,062$ dan $p=0,122)$. Tingkat kecukupan lemak subjek sebagian besar kurang dan hasil penelitian menunjukan adanya hubungan tingkat kecukupan lemak dengan serum retinol $(p=0,024)$. Subjek dengan tingkat kecukupan lemak kurang berisiko memiliki serum retinol rendah. Mengkonsumsi makanan mengandung lemak pada anakanak akan meningkatkan serum retinol sama dengan penambahan makanan sumber beta-karoten (26). Tingkat penyerapan vitamin A sangat tergantung pada kecukupan konsumsi lemak,upaya pengolahan sayuran menjadi sayur bersantan (sayur bobor atau lodeh) dan yang ditumis dengan sedikit minyak (oseng-oseng) akan jauh lebih baik dibandingkan dengan sayur bening atau lalap dan serum vitamin A menjadi tinggi setelah diberikan lemak ke dalam makanan (27).

Hasil penelitian menunjukan tidak adanya hubungan yang signifikan antara tingkat kecukupan 
energi, protein, dan lemak dengan morbiditas subjek $(\mathrm{p}=0,248 ; \mathrm{p}=0,261 ; \mathrm{p}=0,198)$. Hal ini kemungkinan disebabkan oleh banyak faktor lain yang mempengaruhi morbiditas seperti lingkungan, sumber penyakit (agens), dan pejamu (host) (28). Berbeda dengan asupan protein yang menunjukkan tidak adanya hubungan dengan kejadian ISPA pada anak, hal ini karena ISPA tidak hanya dipengaruhi oleh asupan protein dan zink saja, melainkan terdapat banyak faktor yang tidak diteliti yang dapat menjadi penyebab munculnya ISPA seperti asupan vitamin $C$, vitamin $B$, vitamin $D$, vitamin $E$, dan vitamin A yang dapat menurunkan imunitas yang pada akhirnya akan meningkatkan risiko terkena penyakit ISPA (29). Lemak merupakan pelarut beberapa vitamin larut lemak serta berperan penting untuk ketersediaan asam lemak, linoleat, dan asam linolenat. Asam lemak esensial harus tersedia minimal 4\% dari jumlah kkal makanan untuk mencegah defisiensi $(30,31)$.

Vitamin A, vitamin C, dan zink berfungsi untuk pemeliharaan kesehatan dan kelangsungan hidup melalui sistem imunitas. Kekurangan vitamin A dapat mempengaruhi serum retinol dalam darah, sementara vitamin $\mathrm{C}$ dan zink dapat meningkatkan risiko anak terhadap penyakit infeksi seperti penyakit saluran pernafasan, diare, dan demam. Meningkatnya penyakit infeksi dapat menyebabkan keterlambatan pertumbuhan (10). Tingkat kecukupan vitamin A subjek sebagian besar tergolong kurang. Hasil penelitian menunjukan terdapat hubungan antara tingkat kecukupan vitamin A dengan serum retinol subjek $(\mathrm{p}=0,002)$. Tingkat kecukupan vitamin A yang kurang, berisiko terhadap rendahnya kadar serum retinol dalam darah subjek. Salah satu faktor yang mempengaruhi serum retinol dalam darah adalah asupan vitamin A yang disimpan dalam hati (32). Hasil penelitian menunjukan terdapat hubungan tingkat kecukupan vitamin A dengan morbiditas subjek $(\mathrm{p}=0,015)$. Tingkat kecukupan vitamin A yang kurang, berisiko memiliki morbiditas tinggi pada subjek. Timbulnya penyakit infeksi serta berkurangnya sistensis retinol dalam memproses infeksi dan berdampak pada sistem imun disebabkan oleh defisiensi vitamin A. Vitamin A berperan penting dalam pemeliharaan sel epitel oleh karena vitamin A sangat berperan dalam imunitas (29). Kekurangan asupan vitamin A berisiko 1,69 kali untuk terjadinya diare, batuk, dan demam. Dengan demikian, asupan vitamin A yang cukup sangat penting untuk melindungi kesehatan anak di negara berkembang (33).

Lebih lanjut, hasil analisis menunjukkan tingkat kecukupan vitamin $\mathrm{C}$ dan zink sebagian besar subjek tergolong kurang dan tidak menunjukkan adanya hubungan antara tingkat kecukupan vitamin $\mathrm{C}$ dan zink dengan serum retinol subjek $(\mathrm{p}=0,143 ; \mathrm{p}=0,382)$. Namun, ditemukan adanya hubungan tingkat kecukupan vitamin $\mathrm{C}$ dan zink dengan morbiditas subjek ( $\mathrm{p}=0,004 ; \mathrm{p}=0,000)$. Tingkat kecukupan vitamin $\mathrm{C}$ dan zink yang kurang, berisiko memiliki morbiditas tinggi pada subjek. Asupan vitamin $\mathrm{C}$ dapat meningkatkan beberapa komponen dalam tubuh yang berfungsi untuk kekebalan tubuh seperti anti-mikrobisida, limfosit proliferasi, kemotaksis, dan respon imun (34). Fungsi imun dengan menstimulasi produksi interferon (protein yang melindungi sel dari serangan virus) dapat ditingkatkan dengan vitamin $\mathrm{C}$ (35). Di samping itu, ditemukan juga adanya hubungan antara kejadian ISPA dengan konsumsi zink subjek. Hal tersebut sesuai dengan hasil penelitian sebelumnya yang menunjukkan bahwa salah satu fungsi zink adalah sebagai zat gizi yang meningkatkan sistem imunitas dan meningkatkan kerja vitamin A sehingga dapat mengurangi risiko penyakit infeksi (36).

Serum retinol merupakan cerminan kandungan serum vitamin A dalam darah dan akan berpengaruh pada perkembangan pertumbuhan dan kesehatan anak. Sebagian besar serum retinol subjek tergolong normal dan hasil penelitian menunjukan adanya hubungan serum retinol dengan morbiditas subjek $(\mathrm{p}=0,006)$. Kadar serum retinol normal pada subjek memiliki morbiditas rendah. Serum retinol merupakan faktor yang mempengaruhi kejadian morbiditas ISPA dan diare pada anak (37). Dilaporkan juga bahwa penyakit infeksi dan asupan vitamin A merupakan faktor penentu serum retiol darah anak di Zambia (38).

\section{SIMPULAN DAN SARAN}

Suplementasi vitamin A subjek relatif tidak lengkap $(48,6 \%)$. Tingkat kecukupan energi dan protein subjek sebagian besar tergolong defisit sementara tingkat kecukupan lemak, vitamin A, vitamin C, dan zink 
tergolong kurang. Serum retinol subjek relatif normal $(87,9 \%)$ dan morbiditas relatif tinggi $(57,1 \%)$. Variabel yang memiliki pengaruh terhadap serum retinol adalah suplementasi vitamin A, tingkat kecukupan lemak, dan tingkat kecukupan vitamin A. Anak yang tidak mengambil kapsul vitamin A serta asupan vitamin A, vitamin $\mathrm{C}$, zink, dan retinol serum yang rendah memiliki morbiditas yang lebih tinggi.

Menurunkan angka morbiditas pada anak diperlukan peningkatan kesadaran akan pentingnya pemberian asupan zat gizi dan suplementasi vitamin A pada anak melalui program penyuluhan yang dapat meningkatkan pengetahuan gizi dan kesehatan ibu dengan bantuan petugas kesehatan dan masyarakat setempat. Perlu adanya pemeriksaan status vitamin A secara berkala untuk mencegah terjadinya difesiensi vitamin A pada anak.

\section{UCAPAN TERIMAKASIH}

Penulis mengucapkan terimakasih kepada Erry Yudhya Mulyani, M.Sc (Univeristas Esa Unggul) dan Danone Institut Indonesia yang telah mengizinkan penulis bergabung dan menggunakan beberapa data dalam penelitian besar yang berjudul "Fortifikasi vitamin A pada minyak goreng curah di akhir distribusi dan dampaknya pada status vitamin A anak prasekolah“.

\section{Pernyataan konflik kepentingan}

Penulis menyatakan tidak ada konflik kepentingan dengan pihak-pihak yang terkait dalam penelitian ini

\section{RUJUKAN}

1. Kementerian Kesehatan Republik Indonesia. Undangundang Kesehatan No.36 Tahun 2009

2. Haryono R. Keperawatan medikal bedah sistem pencernaan. Yogyakarta: Gosyen Publishing; 2012.

3. Widoyono. Penyakit tropis epidemiologis, penularan, pencegahan, dan pemberantasannya. Jakarta: Erlangga Medical Series; 2008.

4. World Health Organization (WHO). Pakistan: IDP hosting and crisis affected districts, Khyber, Pakhtunkhwa, week 21, 22-28 May 2010. WHO: Weekly Morbidity and Mortality Report; 2010.
5. Kementerian Kesehatan Republik Indonesia. Buletin jendela data dan informasi kesehatan volume 2 triwulan 2. Jakarta: Kementerian Kesehatan RI; 2013.

6. Kementerian Kesehatan Republik Indonesia. Laporan riset kesehatan dasar nasional tahun 2013. Jakarta: Badan Penelitian dan Pengembangan Kesehatan, Kemenkes RI; 2013.

7. Dinas Kesehatan Republik Indonesia. Buku profil kesehatan Provinsi Jawa Tengah tahun 2012. Semarang; Dinas Kesehatan RI; 2013.

8. Haidar J, Tsegaye D, Mariam DH, Tibeb HN, Muroki NM. Vitamin A supplementation on child morbidity. East African Med J 2003;80(1):17-21.

9. Anugraheni HS, Kartasurya MI. Faktor risiko kejadian stunting pada anak usia 12-36 bulan di Kecamatan Pati, Kabupaten Pati [Tesis]. Semarang: Universitas Diponegor; 2012.

10. Almatsier S. Prinsip dasar ilmu gizi. Jakarta: Gramedia Pustaka Utama; 2004.

11. Gibson RS. Principles of Nutritional Assesment. New York: Oxford University Press; 2005.

12. Sommer A, West KP. Vitamin A deficiency : health, survival, and vision. New York: Oxford University Pr; 1996.

13. Karyadi E, West CE, Schltink W, Nelwan R, Gross R, Meer $\mathrm{J}$, et al. A doubleblind, placebo-cotrolled study of vitamin A and zinc supplementation in persons with tuberculosis in Indonesia: effect on clinical response and nutritional status. Am J Clin Nutr 2002;75(4):720-7.

14. Steel RGD, Torrie JH. Prinsip dan prosedur statistika suatu pendekatan biometrik. Jakarta: PT. Gramedia; 1991.

15. Sandjaja, Sudikno, Jus'at I. Konsumsi minyak goreng dan vitamin A pada beberapa kelompok umur di dua kabupaten. Penelitian Gizi dan Makanan 2015;38(1):1-10.

16. Food and Agriculture Organization (FAO). Interim summary of conclusions and dietary recommendations on total fat \& fatty acids. Geneva: FAO/WHO Expert Consultation on Fats and Fatty Acids in Human Nutrition; 2008.

17. Departemen Kesehatan. Deteksi dan tatalaksana kasus xeroftalmia, pedoman bagi tenaga kesehatan. Jakarta: Direktorat Jendral Pembinaan Kesehatan Masyarakat; 2003.

18. Kementerian Kesehatan Republik Indonesia. Angka kecukupan gizi (AKG) 2013. Jakarta: Kementerian Kesehatan RI; 2013.

19. Departemen Kesehatan. Buku pedoman akselerasi cakupan kapsul vitamin A. Jakarta: Departemen Kesehatan; 2000.

20. Paiva A, Rondó PHC, Reinaldo LGC, Pedraza DF, Ruz M. The effect of vitamin A supplementation on retinol concentrations of children with anaemia. Nutria Hospitalaria 2012;27(6):2151-2. 
21. Ferraz IS, Daneluzzi, Vannucchi H, Jordao Jr.AA, Ricco RG, Flores H, et al. Detection of vitamin A deficiency in Brazilian preschool children using the serum 30-day doseresponse test. Eur J Clin Nutr 2004;58(10):1372-7.

22. Rosales FJ. Vitamin A supplementation of vitamin a deficient measles patients lowers the risk of measlesrelated pneumonia in Zambian children. J Nutr 2002;132(12):3700-3.

23. Imdad A, Yacob MY, Sudfeld C, Haider BA, Black RE, Bhutta ZA. Impact of vitamin A supplementation on infant and childood mortality. BMC Public Health 2011;11(Suppl 3):S20.

24. Saifuddin. Hubungan suplementasi vitamin A dengan status kesehatan balita di Kecamatan Jeumpa Kabupaten Bireun [Tesis]. Medan: Universitas Sumatera Utara Medan; 2009.

25. Ridwan E. Kapsul vitamin A dan morbiditas anak balita: analisis data Riskesdas 2007. Gizi Indonesia 2012;35(1):64-72.

26. Jalal F, Nesheim MC, Agus Z, Sanjur D, Habicht JP. Serum retinol concentrations in children are affected by food sources of $\beta$-carotene, fat intake, and antehelminthic drug treatment. Am J Clin Nutr 1998;68:623-9.

27. Almatsier S. Prinsip dasar pangan dan gizi. Jakarta: Gramedia Pustaka Utama; 2011.

28. Widoyono. Penyakit tropis epidemiologi penularan dan pemberantasannya. Jakarta (ID): Erlanggga; 2005.

29. Maitatorum E, Zulaekah S. Status gizi, asupan protein, asupan seng dan kejadian ISPA anak balita di perkampungan kumuh Kota Surakarta. Jurnal Kesehatan 2011;4(1):2130 .
30. Cresci G, Martindale R. Nutrition in critical illness. Dalam: Berdanier C, Dwyer J, Feldman E, penyunting. Handbook of nutrition and food. Edisi ke 2. London: CRC Press; 2008.

31. Heys S, Schofield A, Wahle W. Immunonutrition in clinical practice: what is the current evidence. Nutr Hosp 2004;14(6):325-32.

32. Almatsier S, Soetardjo S, Soekatri M. Gizi seimbang dalam daur kehidupan. Jakarta: Gramedia Pustaka Utama; 2011.

33. Fawzi WW, Herrera MG, Willett WC, Nestel P, el Amin A, Mohamed KA. Dietary vitamin A intake and the incidence of diarrhea and respiratory infection amnong Sudanese children. J Nutr 1995;125(5):1211-21.

34. Wintergerst ES, Maggini S, Hornig DH. Contribution of selected vitamins and trace elements to immune function. Ann Nutr Metab 2007;51(4):301-23.

35. Winarsi H. Antioxidan alami dan radikal bebas. Jogyakarta: Kanisius; 2007.

36. Fitriyah R and Mahmudiono T. Hubungan asupan dan pola konsumsi vitamin A, protein dan zinc dengan kejadian ISPA dan status gizi pad anak. Media Gizi Indonesia 2013;9:60-5.

37. Fedriyansyah, Nazir HZ, Theodorus, Husin S. Hubungan kadar seng dan vitamin A dengan kejadian ISPA dan diare pada anak. Sari Pediatri 2010;12(4):241-6.

38. Hotz C, Chileshe J, Siamusantu W, Palaniappan U, Kafwembe E. Vitamin A and infection are associated with plasma retinol among pre-school children in rural Zambia. Public Health Nutr 2012;15(9):1688-96. 